\title{
Characterization of $\mathrm{Na}^{+} / \mathrm{H}^{+}$exchanger NHE8 in cultured renal epithelial cells
}

\author{
Jianning Zhang $1,{ }^{*}$, Ion Alexandru Bobulescu $1,4,{ }^{*}$, Sunita Goyal ${ }^{5}$, Peter S. Aronson ${ }^{5}$, \\ Michel G. Baum ${ }^{1,2}$, and Orson W. Moe ${ }^{1,3,4}$ \\ ${ }^{1}$ Department of Internal Medicine, University of Texas Southwestern Medical Center, Dallas, \\ Texas \\ 2 Department of Pediatrics, University of Texas Southwestern Medical Center, Dallas, Texas \\ ${ }^{3}$ Department of Physiology, University of Texas Southwestern Medical Center, Dallas, Texas \\ ${ }^{4}$ Charles and Jane Pak Center of Mineral Metabolism and Clinical Research, University of Texas \\ Southwestern Medical Center, Dallas, Texas \\ ${ }^{5}$ Department of Medicine, Yale University School of Medicine, New Haven, Connecticut
}

\begin{abstract}
NHE8 is expressed in the apical membrane of the proximal tubule and is predicted to be a $\mathrm{Na}^{+} / \mathrm{H}^{+}$ exchanger on the basis of its primary amino acid sequence. Functional characterization of native NHE8 in mammalian cells has not been possible to date. We screened a number of polarized renal cell lines for the plasma membrane $\mathrm{Na}^{+} / \mathrm{H}^{+}$exchangers (NHE1, 2, 3, 4, and 8) and found only NHE1 and NHE8 transcripts in NRK cells by RT-PCR. NHE8 protein is expressed in the apical membrane of NRK cells as demonstrated by immunoblots, confocal fluorescent immunocytochemistry, and immunoelectron microscopy. NHE1, on the other hand, is expressed primarily in the basolateral membrane. Bilateral perfusion of NRK cells grown on permeable supports shows $\mathrm{Na}^{+} / \mathrm{H}^{+}$exchange activity on both the apical and basolateral membranes. NHE8specific small interfering RNA knocks down NHE8 protein expression but does not affect NHE1 protein levels. Knockdown of NHE8 protein is accompanied by a commensurate reduction in apical NHE activity, without altered basolateral NHE activity. Conversely, transfection of NHE1specific small interfering RNA knocks down NHE1 protein expression without affecting NHE8 protein levels and reduces basolateral NHE activity without affecting apical NHE activity. NHE8 is the only apical membrane $\mathrm{Na}^{+} / \mathrm{H}^{+}$exchanger in NRK cells. NHE8 activity is $\mathrm{Na}^{+}$dependent, displaying a cooperative sigmoidal relationship, and is highly sensitive to 5-( $N$-ethyl- $n$-isopropyl)amiloride (EIPA). NRK cells provide a useful system where NHE8 can be studied in its native environment.
\end{abstract}

\section{Keywords}

sodium/proton exchanger; sodium/hydrogen exchanger; proximal tubule

Sodium/proton $\left(\mathrm{Na}^{+} / \mathrm{H}^{+}\right)$exchange is an ubiquitous biological process mediated by integral plasma membrane proteins in cells of all kingdoms. Genes coding for $\mathrm{Na}^{+} / \mathrm{H}^{+}$exchangers (NHEs) have been cloned from the simplest prokaryotes (including Archaea) to the most

\footnotetext{
Address for reprint requests and other correspondence: O. W. Moe, Dept. of Internal Medicine, Univ. of Texas Southwestern Medical Center, 5323 Harry Hines Blvd., Dallas, TX 75390-8856 (orson.moe@ utsouthwestern.edu).

J. Zhang and I. A. Bobulescu contributed equally to this work.
} 
advanced multicellular eukaryotes. The human genome contains nine NHE paralogous isoforms, NHE1-9, with different tissue and subcellular distributions, and one spermspecific NHE $(10,20)$. On the bases of their sequence, cellular location, ion selectivity, and inhibitor specificity, eukaryotic NHEs have been divided into intracellular and plasma membrane subfamilies (10). NHE8 was categorized in a distinct clade (NHE8-like) within the intracellular NHE subfamily (10). NHE8 transcript is ubiquitous, with the highest levels in the kidney, mostly in the proximal tubule (14). When transfected into heterologous systems, NHE8 is an intracellular protein $(14,18)$. However, in native kidney tissue, NHE8 has also been localized to the apical membrane of the proximal tubule $(5,13)$.

$\mathrm{Na}^{+} / \mathrm{H}^{+}$exchangers are widely distributed in the kidney with segment- and membranespecific patterns of expression (9). A principal effector of proximal tubule $\mathrm{NaCl}$ and $\mathrm{NaHCO}_{3}$ reabsorption is apical membrane $\mathrm{Na}^{+} / \mathrm{H}^{+}$exchange (NHE), which is predominantly mediated by the NHE3 isoform in adults $(2,6)$. Mice with genetic deletion of both NHE2 and 3 only have a 50\% reduction in proximal tubule $\mathrm{Na}^{+}$-dependent $\mathrm{H}^{+}$ secretion compared with wild-type mice, suggesting the presence of another apical NHE isoform in adult proximal tubule (12). The neonatal proximal tubule exhibits significant apical membrane NHE activity despite a paucity of apical NHE3 expression $(3,4,22)$. NHE8 has peak expression in cortical brush border membranes in 7- to 14-day-old rats with diminished expression in the adult rat brush border (5), suggesting that NHE8 is the principal neonatal apical membrane NHE isoform. Despite a lower brush border expression, total renal NHE8 protein remains high in adult rats (5), suggesting that NHE8 insertion into the brush border may be a regulatory point.

To date it has not been possible to express mammalian NHE8 at the plasma membrane of cultured cells $(13,18)$. The only successful attempt in functional characterization of a mammalian NHE8 was by Nakamura and coworkers (18), who expressed recombinant mouse NHE8 in yeast, solubilizing and reconstituting it into artificial proteoliposomes. In this reconstituted system, NHE8 exchanges either $\mathrm{Na}^{+}$or $\mathrm{K}^{+}$for $\mathrm{H}^{+}$, which is more reflective of an intracellular than an apical membrane NHE. A similar approach was employed by Kang'Ethe and coworkers (15) to characterize the transport kinetics of an insect homolog (AeNHE8) from the mosquito Aedes aegypti. The present study aimed to identify a mammalian polarized cell line with kidney characteristics in which NHE8 is natively expressed on the apical membrane, characterize the transport function of native apical membrane NHE8 and establish a system in which the function and regulation of native NHE8 can be further investigated.

\section{EXPERIMENTAL PROCEDURES}

\section{Materials and supplies}

All chemicals were obtained from Sigma (St. Louis, MO), except where otherwise noted, and except for the following: culture media, Lipofectamine 2000, TRIzol reagent, ThermoScript RT-PCR system and BCECF-AM (Invitrogen, Carlsbad, CA); penicillin and streptomycin (Cambrex, East Rutherford, NJ); EZ-Link sulfo-NHS-SS-biotin and immunopure immobilized streptavidin (Pierce, Rockford, IL); horseradish peroxidaselabeled anti-mouse IgG and blotting-grade nonfat dry milk (Bio-Rad Laboratories, Hercules, CA); enhanced chemiluminescence detection kit (Amersham Biosciences, Piscataway, NJ); polyvinylidene difluoride membranes (Immobilon, Millipore, Billerica, MA).

\section{Cell culture}

NRK cells (normal rat kidney polarized epithelial cells, American Type Culture Collection, Manassas, VA) cultured at $37^{\circ} \mathrm{C}$ in a $95 \%$ air-5\% $\mathrm{CO}_{2}$ atmosphere were passaged in high- 
glucose (450 mg/dl) DMEM supplemented with $10 \%$ fetal bovine serum, penicillin (100 U/ $\mathrm{ml})$, and streptomycin $(100 \mathrm{~g} / \mathrm{ml})$. Before study, confluent cells were rendered quiescent by incubation in serum-free DMEM.

\section{RT-PCR}

Total cellular RNA was extracted by using TRIzol reagent, and cDNA was obtained by oligo(dT) primed reverse transcription using the ThermoScript system $\left(50^{\circ} \mathrm{C}, 40 \mathrm{~min}\right)$. PCR was performed for 30 cycles with denaturation at $94^{\circ} \mathrm{C}(30 \mathrm{~s})$, annealing at $53^{\circ} \mathrm{C}(40 \mathrm{~s})$, and extension at $72^{\circ} \mathrm{C}(4 \mathrm{~min})$. The following rat NHE isoform-specific primers were used for PCR: NHE1 forward 5'-AGTCTGTGGACCTGGTGAAT-3', NHE1 reverse 5'CACTAGCCTGGCTCTACTGC-3'; NHE2 forward 5'CAGCGCACATTGTCCTACAA-3', NHE2 reverse 5'-TGTCCGAGTCGCTGCTATTA-3'; NHE3 forward 5'-AATCTCGAGATCGGATCCTG-3', NHE3 reverse 5'CTCTGTTCCAAGGACTGCAT-3'; NHE4 forward 5'GGCTGGGATTGAAGATGTATGT-3', NHE4 reverse 5'GCTGGCTGAGGATTGCTGTAA-3'; NHE8 forward 5'GTGTGTTTGCATTTCTTGGCCT-3', NHE8 reverse 5'AAGGGGTTCAGATACTTGGCAT-3'.

\section{Antibodies and immunoblotting}

The following primary antibodies were used: anti-NHE8 monoclonal antibody 7A11 (13), anti-NHE1 monoclonal antibody 4E9 and chicken anti-rat NHE1 polyclonal antibody (Chemicon/Millipore, Billerica, MA), rabbit anti-rat NHE3 polyclonal antibody no. 1314 (2), and anti- $\beta$-actin monoclonal antibody (Sigma). Immunoblotting was performed as described previously (8). Briefly, NRK cells were homogenized in RIPA buffer (150 mM $\mathrm{NaCl}, 50 \mathrm{mM}$ Tris. $\mathrm{HCl}, \mathrm{pH} 7.4,5 \mathrm{mM}$ EDTA, $1 \%$ Triton X-100, 0.5\% deoxycholate, and $0.1 \%$ SDS $)$ containing fresh protease inhibitors and cleared by centrifugation $(14,000 \mathrm{~g}$, $4^{\circ} \mathrm{C}, 30 \mathrm{~min}$ ), and protein content was determined by the method of Bradford. Identical amounts of protein were heated for $2 \mathrm{~min}$ at $95^{\circ} \mathrm{C}$ in loading buffer, size fractionated by SDS-PAGE, and electrophoretically transferred to polyvinylidene difluoride membranes. Membranes were blocked in nonfat milk, probed overnight at $4^{\circ} \mathrm{C}$ with the appropriate primary antibody, washed ( $0.05 \%$ Tween 20 in PBS), incubated with a horseradish peroxidase-labeled secondary antibody for $1 \mathrm{~h}$, washed as above, and visualized by enhanced chemiluminescence. For reprobing, membranes were first stripped (30 min at $50^{\circ} \mathrm{C}$ in $0.125 \mathrm{M}$ Tris. $\mathrm{HCl}, \mathrm{pH} 6.7$, with $4 \%$ SDS and $0.016 \% \beta$-mercaptoethanol) and then reprobed as above. Protein abundances were quantified by densitometry using the Scion/ NIH Image software (Scion, Frederick, MD).

\section{Apical membrane protein expression}

Confluent quiescent cells were rinsed with ice-cold isotonic wash buffer as above and surface proteins were biotinylated by incubating cells with $1.5 \mathrm{mg} / \mathrm{ml}$ sulfo-NHS-SS-biotin in $10 \mathrm{mM}$ triethanolamine (pH 7.4), $2 \mathrm{mM} \mathrm{CaCl}_{2}$, and $150 \mathrm{mM} \mathrm{NaCl}$ for $90 \mathrm{~min}$ with horizontal motion at $4^{\circ} \mathrm{C}$. After labeling, plates were washed twice with $6 \mathrm{ml}$ of quenching buffer (PBS containing $1 \mathrm{mM} \mathrm{MgCl}_{2}, 0.1 \mathrm{mM} \mathrm{CaCl}_{2}$, and $100 \mathrm{mM}$ glycine) for $20 \mathrm{~min}$ at $4^{\circ} \mathrm{C}$. Cells were then lysed in RIPA buffer with protease inhibitors as above, lysates were cleared by centrifugation, and the supernatants were diluted to $2.5 \mathrm{mg} / \mathrm{ml}$ of protein with RIPA buffer. Cell lysates of equivalent amount of protein were equilibrated overnight with streptavidin-agarose beads at $4^{\circ} \mathrm{C}$. Beads were washed sequentially with solutions $A(50 \mathrm{mM}$ Tris· $\mathrm{HCl}, \mathrm{pH} 7.4,100 \mathrm{mM} \mathrm{NaCl}, 5 \mathrm{mM}$ EDTA), $B(50 \mathrm{mM}$ Tris. $\mathrm{HCl}, \mathrm{pH}$ 7.4, $500 \mathrm{mM}$ $\mathrm{NaCl})$, and $C(50 \mathrm{mM}$ Tris. $\mathrm{HCl}, \mathrm{pH}$ 7.4). Biotinylated proteins were released by heating to $95^{\circ} \mathrm{C}$ in loading buffer and subjected to immunoblotting as above. 


\section{Immunocytochemistry}

NRK cells were fixed in 4\% paraformaldehyde in PBS for 10 min, permeabilized in $0.1 \%$ Triton X-100 in PBS for 3 min, and blocked by 1.5\% BSA and 10\% goat serum in PBS for 1 h. Specimens were incubated with anti-NHE8 monoclonal antibody (1:50 dilution) overnight at $4{ }^{\circ} \mathrm{C}$, followed by incubation with FITC-conjugated goat anti-mouse antibody $(1: 800$ dilution, Invitrogen) for $1 \mathrm{~h}$ and rhodamine-conjugated phalloidin (1:50 dilution, Invitrogen) for $20 \mathrm{~min}$. Images were visualized with a Zeiss LSM-510 confocal microscope.

\section{Immunoelectron microscopy}

NRK cells grown on permeable filters $(0.4-\mu \mathrm{m}$ pore size, Corning) were fixed in $4 \%$ paraformaldehyde at $4^{\circ} \mathrm{C}$ for $20 \mathrm{~min}$. The immunogold labeling of ultrathin frozen sections was performed according to the method of Tokuyasu (23). The cells were infiltrated with 2.3 $\mathrm{M}$ sucrose overnight and frozen in liquid nitrogen, and $80-\mathrm{nm}$ sections were cut on a Leica ultracryomicrotome (Leica Ultracut UCT) and mounted on Formvar-coated nickel grids. The sections were processed with the following steps: rehydration with PBS containing $20 \mathrm{mM}$ glycine for 10 min followed by PBS; blocking with 1.5\% BSA in PBS for 15 min; incubation with anti-NHE8 monoclonal antibody (1:10) for $60 \mathrm{~min}$; washing with $1.5 \%$ BSA in PBS and then PBS; incubation with colloidal gold-conjugated goat anti-mouse IgG antibody (10-nm gold particles, diluted 1:5, Sigma) for $60 \mathrm{~min}$; washing with PBS; washing in water; and staining with a mixture (8:5:1) of 3\% methylcellulose-water-3\% uranyl acetate. Samples were visualized with a JEOL 1200 EX transmission electron microscope.

\section{NHE activity assays}

NHE activity was measured fluorometrically by using the intracellularly trapped $\mathrm{pH}$ sensitive dye BCECF as described previously (11). Cells grown on either glass coverslips or permeable supports were loaded with $10 \mu \mathrm{M}$ BCECF-AM $\left(25 \mathrm{~min}\right.$ at $\left.37^{\circ} \mathrm{C}\right)$, and intracellular $\mathrm{pH}\left(\mathrm{pH}_{\mathrm{i}}\right)$ was estimated from the ratio of fluorescence (excitation wavelengths: 500 and $450 \mathrm{~nm}$, emission wavelength: $530 \mathrm{~nm}$ ) in a computer-controlled spectrofluorometer (QM-8/2003, Photon Technology International, London, Ontario, Canada). The $500 / 450 \mathrm{~nm}$ fluorescence ratio was calibrated to $\mathrm{pH}_{\mathrm{i}}$ using $\mathrm{K}^{+} /$nigericin as described (1). Bilateral (apical and basolateral) perfusions were performed to separately measure $\mathrm{Na}^{+} / \mathrm{H}^{+}$exchange activity on apical and basolateral membranes. For these experiments, NRK cells were grown to confluence on permeable supports $(0.4-\mu \mathrm{m}$ pore size, Corning, Corning, NY), and epithelial integrity was assessed by both transepithelial electrical resistance and $\left[{ }^{3} \mathrm{H}\right]$ inulin permeability. Cells were loaded with BCECF and mounted in a cuvette chamber where both the apical and basolateral sides can be perfused independently and simultaneously. $\mathrm{Na}^{+}$-containing solution was applied to one side while the opposite side was continuously perfused with a $\mathrm{Na}^{+}$-free solution containing $1 \mathrm{mM}$ of the NHE inhibitor 5-( $N$-ethyl- $n$-isopropyl)-amiloride (EIPA). For $\mathrm{H}^{+}$kinetics experiments, confluent NRK cells were loaded with BCECF and acidified to different $\mathrm{pH}$ values by incubation with the $\mathrm{K}^{+} / \mathrm{H}^{+}$ionophore nigericin at different extracellular $\mathrm{K}^{+}$concentrations. For all experiments $\mathrm{Na}^{+} / \mathrm{H}^{+}$exchange activity was assayed as the initial rate of the $\mathrm{Na}^{+}-$ dependent $\mathrm{pH}_{\mathrm{i}}$ increase after an acid load in the absence of $\mathrm{CO}_{2} / \mathrm{HCO}_{3}^{-}$, and results are reported as $\mathrm{dpH}_{\mathrm{i}} / \mathrm{dt}$, where $\mathrm{t}$ is time. Comparisons were always made between cells of the same passage studied on the same day. For $\mathrm{K}^{+} / \mathrm{H}^{+}$exchange activity experiments, confluent NRK cells were loaded with BCECF and acidified by the $\mathrm{NH}_{4} \mathrm{Cl}$ prepulse method (17), and $\mathrm{K}^{+}$was added to the apical membrane in the absence of external $\mathrm{Na}^{+}$. Exogenously administered nigericin provided a positive control for detection of $\mathrm{K}^{+} / \mathrm{H}^{+}$exchange activity. 


\section{RNA interference}

Small interfering RNA (siRNA) duplexes were designed by using the web-based BLOCK-iT RNAi Designer software from Invitrogen. Knockdown was achieved by cotransfection of two specific nonoverlapping Stealth RNAi duplexes (Invitrogen) per gene. For transfection of siRNA, NRK cells were grown to $50 \%$ confluence in serum-containing DMEM without antibiotics and transfection was performed with Lipofectamine 2000 according to the manufacturer's instructions. Target protein knockdown was measured with different doses of siRNA and at different times after transfection to optimize experimental conditions. The following siRNA oligonucleotides were used: NHE8-siRNA(1) sense 5'AGGCAUUCUCAUGGGAGCAGUUAUA-3', NHE8-siRNA(1) antisense 5'UAUAACUGCUCCCAUGAGAAUGCCU-3'; NHE8-siRNA(2) sense 5'CAGGCUGAUGUAAUCUCUAAACUCA- ${ }^{\prime}$, NHE8-siRNA(2) antisense $5^{\prime}$ UGAGUUUAGAGAUUACAUCAGCCUG-3'; NHE1-siRNA(1) sense 5'UCAUGAAGAUAGGUUUCCAUGUGAU- $3^{\prime}$, NHE1-siRNA(1) antisense $5^{\prime}$ AUCACAUGGAAACCUAUCUUCAUGA-3'; NHE1-siRNA(2) sense 5'AGGACAAGCUCAACCGCUUUAAUAA-3', NHE1-siRNA(2) antisense 5'UUAUUAAAGCGGUUGAGCUUGUCCU-3'.

\section{RESULTS}

\section{Identification of NHE8 transcript in NRK cells}

RT-PCR using isoform-specific primers for all renal plasma membrane $\mathrm{Na}^{+} / \mathrm{H}^{+}$exchangers (7) identified two plasma membrane NHE transcripts in NRK cells, NHE8 and NHE1 (Fig. 1). All PCR products were confirmed by direct sequencing.

\section{Localization of NHE8 protein in NRK cells}

Both NHE8 and NHE1 proteins were detected in total NRK cell lysate by immunoblotting, but only NHE8 was accessible to surface biotinylation of confluent monolayers grown on plastic (Fig. 2A), showing that NHE8 is expressed on the apical membrane. Consistent with the absence of NHE3 mRNA, NHE3 protein was not detected in NRK cells by use of several polyclonal and monoclonal antibodies (not shown). Fluorescence immunocytochemistry (Fig. 2B) and immunogold labeling electron microscopy (Fig. 2C) confirmed the localization of NHE8 at the apical membrane of NRK cells.

\section{Functional characterization of apical NHE8}

To determine whether NHE8 on the apical membrane of NRK cells is a functional $\mathrm{Na}^{+} / \mathrm{H}^{+}$ exchanger, while excluding the potential confounding effects of basolateral NHE1, we measured NHE activity on the apical side of the NRK monolayer while perfusing the basolateral side with a $\mathrm{Na}^{+}$-free isotonic solution containing $1 \mathrm{mM}$ EIPA as described in EXPERIMENTAL PROCEDURES. The high concentration of EIPA and the lack of extracellular sodium, maintained constant by continuous perfusion, exclude the possibility of basolateral $\mathrm{Na}^{+} / \mathrm{H}^{+}$exchange in these conditions. Figure $3 A$ shows a typical tracing of $\mathrm{Na}^{+}$-dependent cell $\mathrm{pH}$ recovery in these conditions. Apical NHE activity is $\mathrm{pH}_{\mathrm{i}}$ dependent (Fig. 3B), sodium dependent displaying a cooperative sigmoidal relationship (Fig. 3C), and highly sensitive to EIPA (Fig. 3D). To determine whether native apical NHE8 also exchanges $\mathrm{K}^{+}$for $\mathrm{H}^{+}$, we looked for potassium-dependent $\mathrm{pH}_{\mathrm{i}}$ recovery after an acid load as described in EXPERIMENTAL PROCEDURES. There was no detectable apical $\mathrm{K}^{+} / \mathrm{H}^{+}$ exchange in NRK cells (Fig. 3E). 


\section{Knockdown of NHE8 in NRK cells}

To confirm that apical NHE activity in NRK cells is mediated by NHE8, we knocked down NHE8 expression by RNA interference. NHE8 protein expression was lowest $72 \mathrm{~h}$ after siRNA transfection, whereas NHE1 expression was not changed (Fig. 4A). Apical NHE activity was significantly reduced $72 \mathrm{~h}$ after siRNA transfection, commensurate with the reduction in NHE8 protein, whereas basolateral NHE activity was not changed (Fig. 4B). These findings constitute a further validation of the apical localization and function of NHE8 in NRK cells.

\section{Knockdown of NHE1 in NRK cells}

To exclude the potential contribution of NHE1 to apical NHE activity, we knocked down NHE1 expression by RNA interference. After $72 \mathrm{~h}$ NHE1 protein expression was significantly reduced, whereas NHE8 expression was not changed (Fig. 5A). Consistent with the presence of NHE1 only on the basolateral membrane, apical membrane NHE activity was not changed, whereas basolateral NHE activity was significantly reduced (Fig. 5B).

\section{DISCUSSION}

We have shown for the first time that native apical membrane NHE8 is a functional $\mathrm{Na}^{+} / \mathrm{H}^{+}$ exchanger in a mammalian cell membrane. NRK cells are polarized cells natively expressing apical membrane NHE8 and basolateral membrane NHE1 and not expressing other plasma membrane NHE isoforms. We have demonstrated that apical $\mathrm{Na}^{+} / \mathrm{H}^{+}$exchange activity in NRK cells is mediated by NHE8.

NHE8 transcript and protein are expressed in the proximal tubule from S1 through S3, and NHE8 protein is detected in brush border membrane vesicles by immunoblot and in the proximal tubule apical membrane by immunohistochemistry using both polyclonal antisera and monoclonal antibodies $(5,13)$. Correspondingly, there is evidence that NHE3 is not the sole mediator of proximal tubule apical $\mathrm{Na}^{+} / \mathrm{H}^{+}$exchange. NHE3-/- mice have only a $50 \%$ reduction in brush border $\mathrm{Na}^{+}$-dependent $\mathrm{H}^{+}$secretion compared with NHE3+/+ mice, and neonatal rat proximal tubules have significant luminal $\mathrm{Na}^{+}$-dependent $\mathrm{H}^{+}$secretion despite almost no apical NHE3 expression. In both cases, the non-NHE3-mediated $\mathrm{Na}^{+} / \mathrm{H}^{+}$ exchange activity has been shown to be sensitive to EIPA $(12,22)$. An insect homolog of mammalian NHE8 has recently been shown to be EIPA sensitive when heterologously expressed in NHE-null rodent fibroblasts (15). Congruently, our study has determined that the activity of native mammalian NHE8 at the apical membrane of NRK cells is highly EIPA sensitive. Taken together, these findings provide strong evidence that proximal tubule apical NHE8 is a functional transporter in vivo.

Congruent with the findings of Nakamura and coworkers (18), NHE8 may also have an intracellular distribution and function. The presence of NHE8 antigen in the poststreptavidin fraction (Fig. 2A) is compatible with this hypothesis. However, one must exercise caution because the presence of NHE8 in the poststreptavidin lysate does not definitively resolve the issue of intracellular NHE8. First, biotinylation may be incomplete owing to hidden lysine residues, and even surface NHE8 may appear in the supernatant. Second, nonbiotinylated NHE8 may just be a reflection of the protein during its normal cycle of intracellular synthesis and trafficking to and from the plasma membrane, which is universal for any membrane protein.

It is noteworthy that the previously reported EIPA sensitivity of the residual NHE activity in NHE3-/- mice (12) is at variance with another published study, which found no component of EIPA-sensitive transtubular bicarbonate absorption in NHE3 null mice (24). However, this apparent contradiction could easily be explained by differences in the execution of the 
respective studies, which are discussed in detail in reference (12). Experimental conditions activating or inhibiting proximal tubular NHE8 could further explain the molecular basis of this discrepancy.

The sigmoidal relationship between extracellular $\mathrm{Na}^{+}$concentration and NHE8 activity in our experiments suggests cooperativity in sodium binding. This finding is different from the Michaelis-Menten sodium kinetics of other NHEs studied in heterologous expression systems $(16,19)$. However, kinetic evidence, suggesting cooperativity of sodium/proton exchange in renal brush border membrane vesicles, has been previously reported, and it has been suggested that cooperativity may result from the association of NHEs in cooperative dimers (21). Our findings may reflect the association of NHE8 proteins in functionally cooperative dimers at the plasma membrane of NRK cells, but further studies are required to investigate this hypothesis.

Of note, it is not appropriate to compare relative expression and activity of apical NHE8 and basolateral NHE1 in cultured cells. These quantitative parameters depend on cell culture conditions (including growth on coverslips and serum deprivation) and would not reflect the relative expression and activity of NHE8 and NHE1 in renal cells in vivo.

Prior to the present study, the function of NHE8 had been examined by using NHE8 protein expressed and purified from yeast and reconstituted in proteoliposomes $(15,18)$. This system is limited by absence of the native plasma membrane milieu, cytoskeleton, and protein interaction network. Moreover, reconstitution in proteoliposomes may actually be a model better reflecting the intracellular function of NHE8, since both $\mathrm{Na}^{+} / \mathrm{H}^{+}$and $\mathrm{K}^{+} / \mathrm{H}^{+}$exchange activity have been described in this system $(15,18)$. There may be significant differences between the function and regulation of the ubiquitously expressed intracellular NHE8 and the renal proximal tubule apical membrane NHE8. The absence of detectable apical K$/ \mathrm{H}^{+}$ exchange in NRK cells could be a reflection of these differences.

This body of data shows that native NHE8 is targeted to the plasma membrane in a mammalian renal cell line and functions as an apical $\mathrm{Na}^{+} / \mathrm{H}^{+}$exchanger. Proximal tubule brush border NHE8 and NHE3 are reciprocally regulated during early post-natal development (5), but the factors involved in these developmental changes and in the regulation of NHE8 require further investigation. NRK cells will furnish a valuable system for further studies on the function and regulation of NHE8.

\section{Acknowledgments}

We are grateful to Dennis J. Bellotto for expert advice in electron microscopy.

\section{GRANTS}

This work was supported by National Institutes of Health grants DK-48482 and DK-20543 (to O. W. Moe), DK-41612 (to M. G. Baum), and R01-DK33793 and P01-DK17433 (to P. S. Aronson) and by a grant from the Simmons Family Foundation (to O. W. Moe). I. A. Bobulescu was the recipient of a Research Fellowship from the Charles and Jane Pak Center for Mineral Metabolism and Clinical Research.

\section{References}

1. Alpern RJ. Mechanism of basolateral membrane $\mathrm{H}+/ \mathrm{OH}-/ \mathrm{HCO}-3$ transport in the rat proximal convoluted tubule. A sodium-coupled electrogenic process. J Gen Physiol. 1985; 86:613-636. [PubMed: 2999293]

2. Amemiya M, Loffing J, Lotscher M, Kaissling B, Alpern RJ, Moe OW. Expression of NHE-3 in the apical membrane of rat renal proximal tubule and thick ascending limb. Kidney Int. 1995; 48:12061215. [PubMed: 8569082] 
3. Baum M. Developmental changes in rabbit juxtamedullary proximal convoluted tubule acidification. Pediatr Res. 1992; 31:411-414. [PubMed: 1315022]

4. Baum M, Biemesderfer D, Gentry D, Aronson PS. Ontogeny of rabbit renal cortical NHE3 and NHE1: effect of glucocorticoids. Am J Physiol Renal Fluid Electrolyte Physiol. 1995; 268:F815F820.

5. Becker AM, Zhang J, Goyal S, Dwarakanath V, Aronson PS, Moe OW, Baum M. Ontogeny of NHE8 in the rat proximal tubule. Am J Physiol Renal Physiol. April 11.2007 10.1152/ajprenal. 00400.2006

6. Biemesderfer D, Pizzonia J, Abu-Alfa A, Exner M, Reilly R, Igarashi P, Aronson PS. NHE3: a Na ${ }^{+}$ $\mathrm{H}^{+}$exchanger isoform of renal brush border. Am J Physiol Renal Fluid Electrolyte Physiol. 1993; 265:F736-F742.

7. Bobulescu IA, Di Sole F, Moe OW. $\mathrm{Na}^{+} / \mathrm{H}^{+}$exchangers: physiology and link to hypertension and organ ischemia. Curr Opin Nephrol Hypertens. 2005; 14:485-494. [PubMed: 16046909]

8. Bobulescu IA, Dwarakanath V, Zou L, Zhang J, Baum M, Moe OW. Glucocorticoids acutely increase cell surface $\mathrm{Na}^{+} / \mathrm{H}^{+}$exchanger-3 (NHE3) by activation of NHE3 exocytosis. Am J Physiol Renal Physiol. 2005; 289:F685-F691. [PubMed: 15942046]

9. Bobulescu IA, Moe OW. $\mathrm{Na}^{+} / \mathrm{H}^{+}$exchangers in renal regulation of acid-base balance. Semin Nephrol. 2006; 26:334-344. [PubMed: 17071327]

10. Brett CL, Donowitz M, Rao R. Evolutionary origins of eukaryotic sodium/proton exchangers. Am J Physiol Cell Physiol. 2005; 288:C223-C239. [PubMed: 15643048]

11. Cano A, Preisig P, Alpern RJ. Cyclic adenosine monophosphate acutely inhibits and chronically stimulates $\mathrm{Na} / \mathrm{H}$ antiporter in OKP cells. J Clin Invest. 1993; 92:1632-1638. [PubMed: 7691881]

12. Choi JY, Shah M, Lee MG, Schultheis PJ, Shull GE, Muallem S, Baum M. Novel amiloridesensitive sodium-dependent proton secretion in the mouse proximal convoluted tubule. J Clin Invest. 2000; 105:1141-1146. [PubMed: 10772659]

13. Goyal S, Mentone S, Aronson PS. Immunolocalization of NHE8 in rat kidney. Am J Physiol Renal Physiol. 2005; 288:F530-F538. [PubMed: 15522984]

14. Goyal S, Vanden Heuvel G, Aronson PS. Renal expression of novel Na ${ }^{+} / \mathrm{H}^{+}$exchanger isoform NHE8. Am J Physiol Renal Physiol. 2003; 284:F467-F473. [PubMed: 12409279]

15. Kang'Ethe W, Aimanova KG, Pullikuth AK, Gill SS. NHE8 mediates amiloride sensitive $\mathrm{Na}^{+} / \mathrm{H}^{+}$ exchange across mosquito Malpighian tubules and catalyzes $\mathrm{Na}^{+}$and $\mathrm{K}^{+}$transport in reconstituted proteoliposomes. Am J Physiol Renal Physiol. Feb 6.2007 10.1152/ajprenal.00487.2005

16. Levine SA, Montrose MH, Tse CM, Donowitz M. Kinetics and regulation of three cloned mammalian $\mathrm{Na}^{+} / \mathrm{H}^{+}$exchangers stably expressed in a fibroblast cell line. J Biol Chem. 1993; 268:25527-25535. [PubMed: 8244988]

17. Moe OW, Miller RT, Horie S, Cano A, Preisig PA, Alpern RJ. Differential regulation of Na/H antiporter by acid in renal epithelial cells and fibroblasts. J Clin Invest. 1991; 88:1703-1708. [PubMed: 1658050]

18. Nakamura N, Tanaka S, Teko Y, Mitsui K, Kanazawa H. Four $\mathrm{Na}^{+} / \mathrm{H}^{+}$exchanger isoforms are distributed to Golgi and post-Golgi compartments and are involved in organelle $\mathrm{pH}$ regulation. $\mathrm{J}$ Biol Chem. 2005; 280:1561-1572. [PubMed: 15522866]

19. Orlowski J. Heterologous expression and functional properties of amiloride high affinity (NHE-1) and low affinity (NHE-3) isoforms of the rat Na/H exchanger. J Biol Chem. 1993; 268:1636916377. [PubMed: 8393860]

20. Orlowski J, Grinstein S. Diversity of the mammalian sodium/proton exchanger SLC9 gene family. Pflügers Arch. 2004; 447:549-565.

21. Otsu K, Kinsella JL, Heller P, Froehlich JP. Sodium dependence of the $\mathrm{Na}^{+}-\mathrm{H}^{+}$exchanger in the pre-steady state. Implications for the exchange mechanism. J Biol Chem. 1993; 268:3184-3193. [PubMed: 8381420]

22. Shah M, Gupta N, Dwarakanath V, Moe OW, Baum M. Ontogeny of $\mathrm{Na}^{+} / \mathrm{H}^{+}$antiporter activity in rat proximal convoluted tubules. Pediatr Res. 2000; 48:206-210. [PubMed: 10926296]

23. Tokuyasu KT. Immunochemistry on ultrathin frozen sections. Histochem J. 1980; 12:381-403. [PubMed: 7440248] 
24. Wang T, Yang CL, Abbiati T, Schultheis PJ, Shull GE, Giebisch G, Aronson PS. Mechanism of proximal tubule bicarbonate absorption in NHE3 null mice. Am J Physiol Renal Physiol. 1999; 277:F298-F302. 


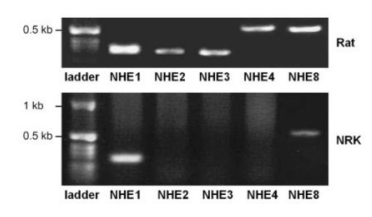

Fig. 1.

Plasma membrane $\mathrm{Na}^{+} / \mathrm{H}^{+}$exchangers expressed in NRK cells. RNA was prepared from confluent quiescent NRK cells, and RT-PCR was performed with rat NHE isoform-specific forward and reverse primers (see EXPERIMENTAL PROCEDURES for primer sequences). All PCR products were confirmed by direct sequencing. Reactions without RT were negative (not shown). Rat kidney RNA served as positive control. 


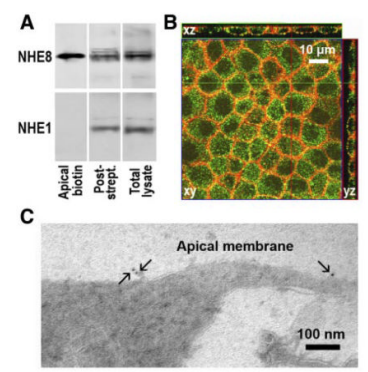

Fig. 2.

Localization of NHE8 protein in NRK cells. $A$ : immunoblot. Confluent quiescent NRK cells were surface labeled with biotin, lysed, and affinity precipitated with strepavidin-agarose.

Biotinylated proteins, nonbiotinylated proteins (poststreptavidin fraction), and total cellular proteins were resolved on SDS-PAGE and immunoblotted for NHE1 (polyclonal antibody) and NHE8. B: immunocytochemistry. Confluent quiescent NRK cells were labeled with mouse anti-NHE8 primary antibody and stained with FITC-conjugated goat anti-mouse secondary antibody (green) and rhodamine-conjugated phalloidin (red). The figure shows 3 different perspectives ( $x y, x z$, and $y z$ planes) of a typical image. The apical membrane of the cells is toward the lower part of the image in the $x z$ cross section and toward the left in the $x y$ cross section. $C$ : immunoelectron microscopy. Confluent quiescent NRK cells were labeled with mouse anti-NHE8 primary antibody and colloidal gold-conjugated goat antimouse secondary antibody. NHE8 labeling on the cell surface is indicated by arrows. 


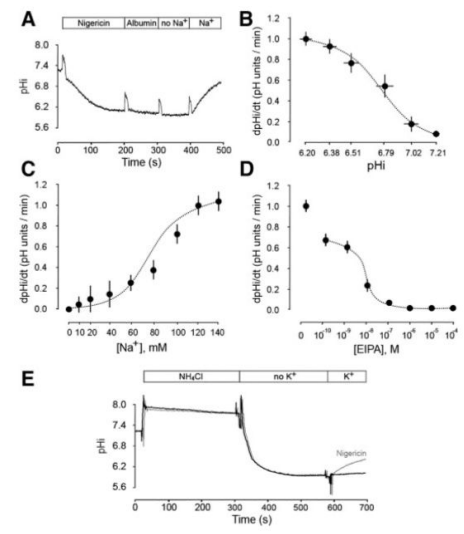

Fig. 3.

Apical NHE8 activity and functional characterization. $A$ : typical tracing of $\mathrm{Na}^{+}$-dependent cell $\mathrm{pH}$ recovery. Confluent NRK cells on permeable supports were loaded with the $\mathrm{pH}$ sensitive fluorescent dye BCECF and mounted in a cuvette chamber where both the apical and basolateral sides can be perfused independently and simultaneously. Cells were acidified by the nigericin method and cell $\mathrm{pH}$ was monitored by epifluorescence. $\mathrm{Na}^{+}$ addition was made to the apical chamber while the basolateral chamber had a $\mathrm{Na}^{+}$-free continuous perfusate containing $1 \mathrm{mM}$ EIPA. $B$ : proton kinetics. NRK cells were acidified to different intracellular $\mathrm{pH}\left(\mathrm{pH}_{\mathrm{i}}\right)$ values by use of nigericin at different extracellular $\mathrm{K}^{+}$ concentrations, and apical $\mathrm{Na}^{+}$-dependent $\mathrm{pH}_{\mathrm{i}}$ recovery was measured with constant external $\left[\mathrm{Na}^{+}\right]$(brackets denote concentration). The data shown is a summary of 3 independent experiments performed on different NRK cells. $C$ : sodium kinetics. Apical $\mathrm{Na}^{+}$-dependent $\mathrm{pH}_{\mathrm{i}}$ recovery after acidification to the same $\mathrm{pH}_{\mathrm{i}}$ by nigericin was measured with different external $\mathrm{Na}^{+}$concentrations. The data shown is a summary of 3 independent experiments performed on different NRK cells. $D$ : ethyl-isopropylamiloride (EIPA) kinetics. Apical $\mathrm{Na}^{+}-$ dependent $\mathrm{pH}_{\mathrm{i}}$ recovery after acidification to the same $\mathrm{pH}_{\mathrm{i}}$ by nigericin was measured with varying amounts of EIPA and constant $\left[\mathrm{Na}^{+}\right]$. The data shown is a summary of 3 independent experiments performed on different NRK cells. $E$ : typical tracings of the $\mathrm{K}^{+} / \mathrm{H}^{+}$ exchange assay. Apical $\mathrm{K}^{+}$-dependent $\mathrm{pH}_{\mathrm{i}}$ recovery after acidification by the $\mathrm{NH}_{4} \mathrm{Cl}$ prepulse method was examined in the absence of external $\mathrm{Na}^{+}$. Exogenously administered nigericin served as positive control. 

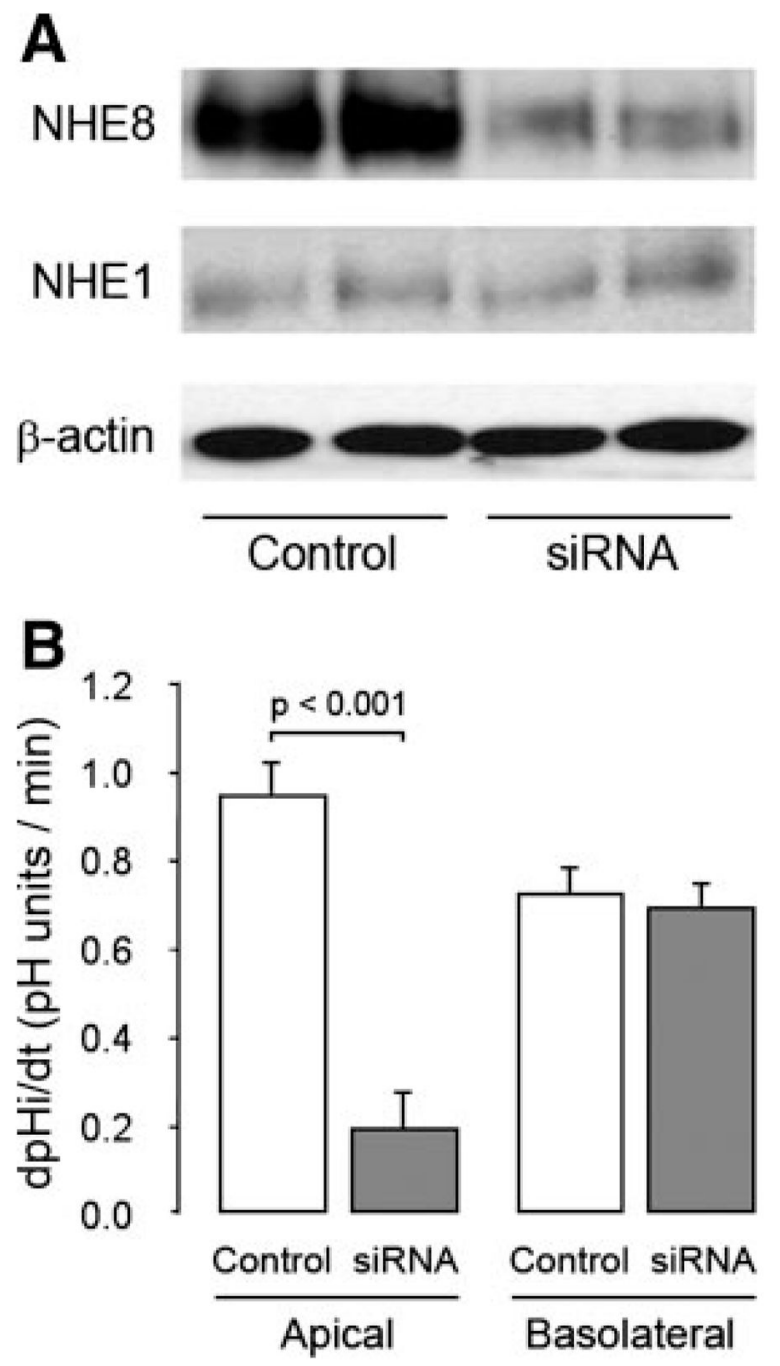

Fig. 4.

Knockdown of NHE8 in NRK cells. A: NRK cells were transfected with 2 sets of NHE8specific small interfering RNA (siRNA) duplexes, and whole cell lysates were resolved on SDS-PAGE and immunoblotted for NHE8 and NHE1 (monoclonal antibody), $72 \mathrm{~h}$ after transfection. $B$ : NHE activity was assayed as $\mathrm{Na}^{+-}$dependent $\mathrm{pH}_{\mathrm{i}}$ recovery after an acid load by use of BCECF fluorescence under $V_{\max }$ conditions for both $\mathrm{Na}^{+}$and $\mathrm{H}^{+}$either on the apical or basolateral surface, $72 \mathrm{~h}$ after transfection with either control or NHE8-specific siRNA. 


\section{A}

NHE1

NHE8

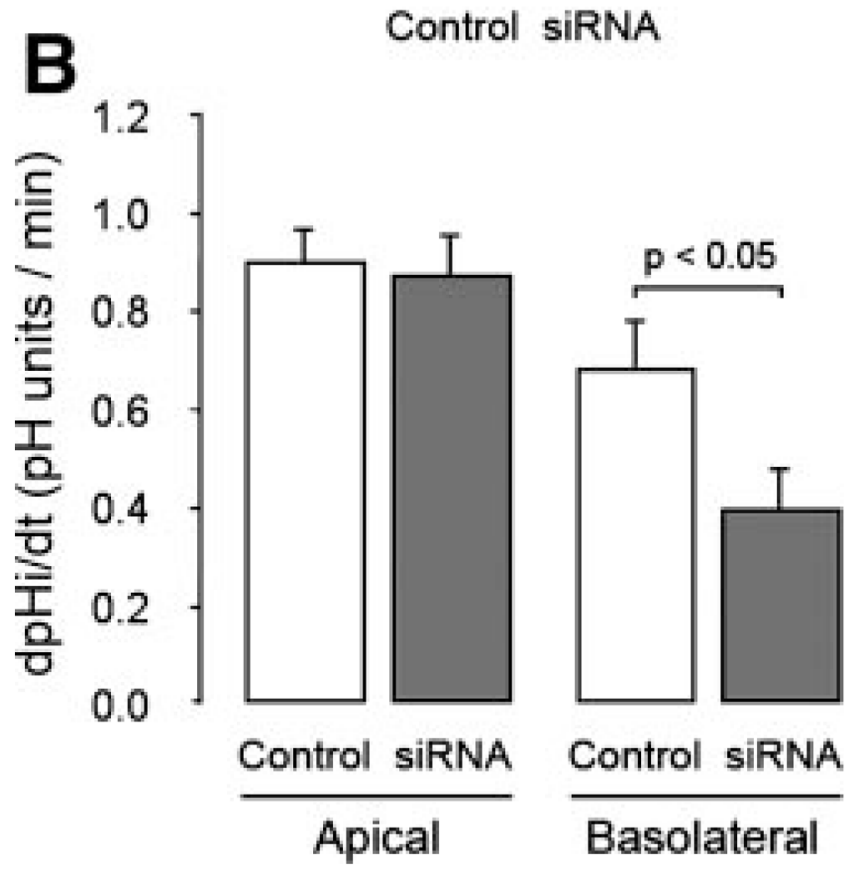

Fig. 5.

Knockdown of NHE1 in NRK cells. A: NRK cells were transfected with 2 sets of NHE1specific siRNA duplexes and whole cell lysates were resolved on SDS-PAGE and immunoblotted for NHE8 and NHE1 (polyclonal antibody), $72 \mathrm{~h}$ after transfection. $B$ : NHE activity was assayed as $\mathrm{Na}^{+}$-dependent $\mathrm{pH}_{\mathrm{i}}$ recovery after an acid load using BCECF fluorescence under $V_{\max }$ conditions for both $\mathrm{Na}^{+}$and $\mathrm{H}^{+}$on either the apical or the basolateral surface, $72 \mathrm{~h}$ after transfection with either control or NHE1-specific siRNA. 